\title{
Self and Cross Compatibility in Some Mango Cultivars
}

\author{
N. H. Nady and Sanaa. S. Ebad \\ Department of Tropical Fruits, Horticultural Research Institute, \\ Agricultural Research Centre, Cairo, Egypt.
}

\begin{abstract}
$\boldsymbol{T}$ THIS STUDY was carried out during 2013 and 2014 seasons in order to study self and cross compatibility among Sedik, Langra and Ewais cultivars. Sedik, Langra, Hindi, Zebda and Ewais were grown in the farm of horticulture research institute, Giza governorate and used as pollinators. The puncle/inflorescence $(\%)$ and fruit set average were recorded in the two seasons. In Sedik the results of puncles/inflorescence (\%) and fruit set were the highest when Sedik was self pollinated. Langra, showed best results when Zebda and Hindi was used as pollinators. Ewais puncles/inflorescence (\%) recorded its best results when pollinated with Sedik and resulted in the best average of fruit set with Zebda. On the other hand, the factors control puncle/inflorescence $\%$ and average fruit set, Anatomical study showed that In Sedik cultivar (stigmas) a few Sedik pollen which could not germinate and the germination was very poor and pollen tube showed abnormal development, they stopped growth early in the style.
\end{abstract}

In Langra cultivar (stegma) Zebda pollen germination was very poor and the pollen tubes grew very slowly and showed abnormalities which led to an earlier cessation of growth. In Ewais cultivar (stegma) Sedik pollen had poor germination the style tissue was senesced

Thus, it can be concluded that, Sedik, pollinators was suitable for Sedik cultivar, However, Hindi and/or Zebda were suitable as pollinators for Langra cultivar. While Sedik and Zebda were suitable pollinators for Ewais.

Keywords: Mango, Pollination, Compatibility.

Most of mango cultivars have low productivity, due to some reasons i.e. the alternate bearing, malformation, lower fruit set and higher fruit drop at different growth stages. Concerning fruit set, it was mainly attributed to the less effective pollination, the limited period of stigmatic and to the protogyny (Spencer and Kennard 1955). Many varieties were found to be self fruitful, but cross pollination seemed to be necessary in order to obtain reasonable crops (Ali and Mazhaar, 1960). Pollination in mango is essential for fruit setting and it is chiefly done by insects (Chandbr, 1958 and Singh, 1960). Natural pollen transfer only initiates fruiting while the stigmas are receptive, that is capable of holding pollen and stimulating germination. The growing pollen tubes take time to affect 
fertilization before the senescence of ovules (Williams et al., 1984). After pollen grain is being transferred to the stigma, it starts germination, then pollen tubes penetrate the stigma and grow down through the style until it enters the loculus, and so to the ovules where fertilizer takes place. Callus in either living or dead tissue can be stained selectively with water soluble aniline blue which fluorescence in ultra violet light (Currier, 1957). Compatible tubes are the most rapidly growing ones at all temperatures and their rate of growth is accelerated by raising temperature (Modlibowska, 1945). Fruit set depends on pollination, pollen tube growth and viability of ovules which must be fertilized. The viability of embryo sacs and ovules of fruit trees is rather short and may be a limiting factor for fruit set, especially if pollination is delayed (Stosser and Anvari, 1983).

As mentioned by Afify (1933), there are grades of pollen tubes, a) nongerminating pollen, b) short pollen tubes bending upwards, c) tubes growing to about one third of the style length and d) tubes penetrating the full length of the style.

High levels of pollen sterling were found in lettuce plants when immature flower buds were sprayed with Ethrel compared with the untreated (Han and Lee, 1972). The pollen grain tubes on stigmatic surface indicate viability and germinability rather than an incompatibility reaction (Schmadlak, 1965). In self pollination, pollen tubes are classified into 3 sections, characterized by a marked incompatibility reaction on the stigmatic surface, short, twisted and sometimes bifurcated. Those penetrating the stigma had an overall deposit of callose and or prominent collose plygs. A few tubes penetrated to maximum of 1 or $2 \mathrm{~mm}$ down the free styles. Stigma penetration was good with a wide variation in pollen tube callose content, but most pollen tubes had some overall deposit together with prominent plygs. No penetration beyond $1.5-3.5 \mathrm{~mm}$. Entry to the styler tube canal and initial growth was similar to that of compatible cross pollination with small; widely spaced callose plays, though, growth is slower. Penetration ceased in the free styles or upper joint stylar column (Williams, 1970).

In computule tubes contained frequent large callose plays, sometimes continuous deposition of callose along the tubes and obvious terminal plays. Cessation of growth was often abrupt, almost all tubes penetrating about $6 \mathrm{~mm}$ and then stop at the junction into the joint style (Stott, 1972). Fluorescencemicroscopic is a method which enables one to determine the viability of ovules at a very early stage (Anvari and Stossar, 1978). In early stages of development; by means of fluorescence microscopic method. The ovaries were stained with aniline blue, it was demonstrated that pollen tubes grew only in ovules which did not show fluorescence. They were not fertilized and must be considered as non viable ovules even cytological they showed a normal development. The aim of the current work was assessed self and cross compatibility in some mango cultivars. 


\section{Materials and Methods}

The present work was carried out through two successive seasons 2013 and 2014 at the orchard of horticulture research institute, Giza governorate, Egypt. Mango trees were about 12 years old, grafted on seedlings of local clone and all trees were treated alike in manuring, mineral fertilization, irrigation and pest control. In each season, healthy trees were selected nearly similar in vigour and size to be used for various treatments. In each season, Sedik, Ewais and Langra mango trees (three replicate of five inflorescences for each replicate) were sprayed at the first pink stage of flowers with Ethrel at $25 \mathrm{ppm}$ to induce complete male sterility (Fig. A). The anthers were tested when they did not burst or produce pollen grains.

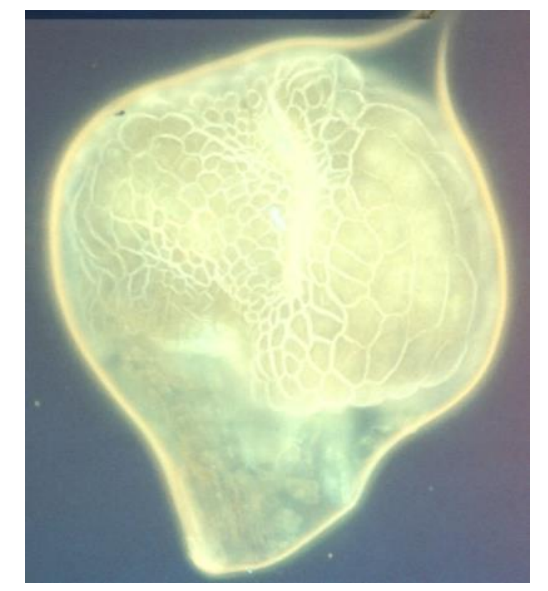

Fig. A. an strell anther as result of Etherl treatment.

In addition, fifteen inflorescence for each variety were sprayed with distilled water and kept as control. Therefore, the following crosses had been done

\begin{tabular}{|l|c|c|c|c|c|}
\hline Pollinator & \multirow{2}{*}{ Sedik } & Zebda & \multirow{2}{*}{ Hindi } & Ewais & Langra \\
\cline { 1 - 5 } Cultivar & $\mathrm{X}$ & $\mathrm{X}$ & $\mathrm{X}$ & $\mathrm{X}$ & $\mathrm{X}$ \\
\hline Sedik & $\mathrm{X}$ & $\mathrm{X}$ & $\mathrm{X}$ & $\mathrm{X}$ & $\mathrm{X}$ \\
\hline Langra & $\mathrm{X}$ & $\mathrm{X}$ & $\mathrm{X}$ & $\mathrm{X}$ & $\mathrm{X}$ \\
\hline Ewais &
\end{tabular}

Flowers of the five studied pollinators (Ewais, Sedik, Langra, Hindi and Zebda) were collected at the balloon stage and kept on paper sheets for over night at room temperature to encourage anthers dehiscence, part of these pollen grains was taken to investigate the pollen viability using triyphenyle tetrazolium chloride (TTC) staining solution. One part of 10\% TTC:10 parts of 60\% sucrose solution (Oberle and Watson, 1953). The percentage of pollen germination was also recorded. Pollinizers were enclosed in pergamin bags at the end of the full pink stage. 
At the pollination times, the previously bagged inflorescences of Ewais, Sedik, Langra, Hindi and Zebda cvs were cut and topped lightly on the emasculated inflorescences of Sedik, Ewais and Langra trees. The pergamin bags were replaced immediately. In order to determine the self and /or cross fertility in Sedik, Ewais and Langra cvs, 15 branches from each cv - were bagged before anthesis and left until petal fall.

Samples of pistils from each cv were taken after 7 days from pollination. Then, they were fixed immediately in E.P.A. (formalin: propionic acid: Ethanol 90:5:5). Samples of pistils were softened in $8 \mathrm{~N} \mathrm{NaOH}$ for 2 hours, washed with tap water for 24 hours and stained in $0.1 \%$ aniline blue (w/s), dissolved in 0.1 $\mathrm{K}_{3} \mathrm{PO}_{4}$ and examined with Lica fluorescence microscope according to the method of Kho and Baer (1970).

When the dissected styles were viewed under the fluorescence microscope (F.M), pollen grain and tubes were readily identified by their brilliant yellow fluorescence, ovule viability was investigated according to Anvari \& stosser (1978) and Abou Elnasr \& Wanas (1992).

Ovules showing very intensive fluorescence were considered as non viable or senescent. After 3 weeks from pollination, the number of setting fruits per panicle was recorded for each treatment. A complete randomized design was used for each study and the obtained data were statistically analysed according to (Snedecor and Cochran, 1980).

\section{Results and Discussion}

Data in Table 1 clearly show that Sedik cultivar receive pollination from it self was better than all other used pollinator cultivars as it recorded $25 \%$ of inflorescences succeed to have a fruit sets as compared to $16.7 \%, 16.7 \%, 8.3 \%$ and $8.3 \%$ for Zepda, Ewais, Hindi and Langra pollinators, respectively.

Langra cultivar received pollinating from Zepda and Hindi was better than all other used pollinators. It recorded $58.3 \%$ inflorescences have a fruit sets followed by Ewais and Sedik pollinators 50.0\% and 41.7\%, respectively. Langra self pollination was the worst, it recorded 16.7 of inflorescences having fruits

Ewais cultivar received pollination from Sedik pollinator $50.0 \%$ followed by Langra and Hindi pollinator $33.3 \%$. Zebda pollinator was considered as a lower pollinator $8.3 \%$ whereas its self pollination was intermediate $25.0 \%$ of inflorescences having fruit sets.

In relation to pollinators: Table 1 show that Sedik pollinators recorded best result with Ewais cultivar $50.0 \%$ of where inflorescences succeeded to have a fruit sets followed by Langra and its self came at the end. Zebda pollinator gave its best result with Langra only $58.3 \%$ of inflorescences succeeded to have a fruit sets and was less with other studied cultivars, Hindi pollinator gave its best result

Egypt. J. Hort. Vol. 42, No. 2 (2015) 
with Langra only $58.3 \%$ of inflorescences succeeded to have a fruit sets flowed by Ewais cultivars $33.3 \%$ of inflorescences succeeded to have a fruit sets and was too few with Sedik $8.3 \%$ of inflorescences succeeded to have a fruit sets. Ewais pollinator showed its best results with Langra 50.0 of inflorescences succeeded to have a fruit sets flowed by Ewais it self 25.0 of inflorescences succeeded to have a fruit sets and Sedik $16.7 \%$ of inflorescences succeeded to have a fruit sets. Langra pollinator give its best result with Ewais $41.7 \%$ of inflorescences succeeded to have a fruit sets and was less with it self $16.7 \%$ of inflorescences succeeded to have a fruit sets and so little with Sedik $8.3 \%$ of inflorescences succeeded to have a fruit sets.

TABLE 1. Percent of inflorescence succeed in average number of fruit set.

\begin{tabular}{|c|c|c|c|c|c|c|c|c|c|c|c|c|c|c|c|}
\hline Pollinator & \multicolumn{3}{|c|}{ Sedik } & \multicolumn{3}{|c|}{ Zebda } & \multicolumn{3}{|c|}{ Hindi } & \multicolumn{3}{|c|}{ Ewais } & \multicolumn{3}{|c|}{ Langra } \\
\hline Cultivar & 2013 & 2014 & AV & 2013 & 2014 & AV & 2013 & 2014 & AV & 2013 & 2014 & AV & 2013 & 2014 & AV \\
\hline Sedik & 25.0 & 25.0 & 25.0 & 16.7 & 16.7 & 16.7 & 8.3 & 8.3 & 8.3 & 8.3 & 25.0 & 16.7 & 8.3 & 8.3 & 8.3 \\
\hline Langra & 50.0 & 33.3 & 41.7 & 50.0 & 66.7 & 58.3 & 50.0 & 66.7 & 58.3 & 58.3 & 41.7 & 50.0 & 25.0 & 8.3 & 16.7 \\
\hline Ewais & 58.3 & 41.7 & 50.0 & 8.3 & 8.3 & 8.3 & 41.7 & 25.0 & 33.3 & 16.7 & 33.3 & 25.0 & 41.7 & 25.0 & 33.3 \\
\hline $\begin{array}{c}\operatorname{LSD}(\mathrm{A}) \\
\operatorname{LSD}(\mathrm{B}) \\
\operatorname{LSD}(\mathrm{AB})\end{array}$ & & $\begin{array}{c}\text { st seas } \\
15.5 \\
12.0 \\
26.8\end{array}$ & & & & $\begin{array}{l}\text { Seco } \\
16.6 \\
12.9 \\
28.7\end{array}$ & & & $\begin{array}{l}\text { A (po } \\
\text { B (cu }\end{array}$ & $\begin{array}{l}\text { nators) } \\
\text { vars) }\end{array}$ & & & & & \\
\hline
\end{tabular}

$\mathrm{AV}=$ average (mean)

Data in Table 2 clearly show that Sedik cultivar fertility to itself was significant better than the other used pollinator cultivars. It recorded 8.6 fruit sets in inflorescences as compared to $6,2.5,1$ and 1 fruit sets inflorescences for Ewais , Zebda, Hindi and Langra, respectively.

The fertility of Langra cultivar when pollinated from Hindi and Zepda was better than all other used pollinators. It recorded 15 and 10.6 fruit sets in inflorescences followed by Sedik 8.6, Zebda 5.5 fruit sets inflorescences and Langra 3 fruit sets inflorescences. Langra self pollination was the worst.

Ewais cultivar fertility to Zebda 55 fruit sets inflorescences followed by Hindi and Langra 24.75 and 23.8 fruit sets, respectively. Ewais self pollination was medium fertile 14.33 fruit sets / inflorescence. Sedik was the worst 8 fruit sets / inflorescence.

In relation to pollinators, Sedik showed regular results with all studied cultivars, it showed 8, 8.6 fruit sets / inflorescence and 8 fruit sets / inflorescence for Sedik, Langra and Ewais, respectively.

Zebda pollinator gave its best result with Ewais only 55 fruit sets / inflorescence and was less with other studied cultivars, Hindi pollinator gave its 
best result with Ewais only 24.75 fruit sets / inflorescence flowed by Langra cultivars 15 fruit sets and was so less with Sedik 1 fruit sets / inflorescence.

Ewais pollinator showed its best results with it self 14.33 fruit sets / inflorescence followed by Langra and Sedik 10.66 and 6 fruit sets / inflorescence respectively. Langra pollinator gave its best result with Ewais 23.8 fruit sets / inflorescence and was less with it self 3 fruit sets and so little with Sedik 1 fruit sets / inflorescence.

TABLE 2. Effect of pollinators and pollinated mango cultivar on Average number of fruit set in cluster.

\begin{tabular}{|c|c|c|c|c|c|c|c|c|c|c|c|c|c|c|c|}
\hline \multirow{2}{*}{$\begin{array}{c}\text { Pollinator } \\
\text { Cultivar }\end{array}$} & \multicolumn{3}{|c|}{ Sedik } & \multicolumn{3}{|c|}{ Zebda } & \multicolumn{3}{|c|}{ Hindy } & \multicolumn{3}{|c|}{ Ewais } & \multicolumn{3}{|c|}{ Langra } \\
\hline & 13 & 14 & AV & 13 & 14 & AV & 13 & 14 & AV & 13 & 14 & AV & 13 & 14 & AV \\
\hline Sedik & 10.0 & 6.0 & 8.0 & 1.0 & 4 & 2.5 & 1.0 & 1.0 & 1.0 & 5.0 & 7.0 & 6.0 & 1.0 & 1.0 & 1.0 \\
\hline Langra & 10.0 & 7.2 & 8.6 & 6.0 & 5.0 & 5.5 & 10.0 & 20.0 & 15.0 & 10.0 & 11.4 & 10.7 & 4.0 & 2.0 & 3.0 \\
\hline Ewais & 7.0 & 9.0 & 8.0 & 40 & 70 & 55 & 22.0 & 27.5 & 24.75 & 12.0 & 16.6 & 14.3 & 27.6 & 20.0 & 23.8 \\
\hline $\begin{array}{l}\text { LSD (A) } \\
\text { LSD (B) } \\
\text { LSD } \\
\text { (AB) }\end{array}$ & $\begin{array}{l}\text { First } \\
\text { seaso } \\
7.0 \\
5.5 \\
12.3\end{array}$ & & $\begin{array}{l}\text { Seco } \\
6.5 \\
5.0 \\
11.3\end{array}$ & $\overline{\mathrm{d} \mathrm{se}}$ & son & & $\begin{array}{l}\mathrm{A}(\mathrm{po} \\
\mathrm{B}(\mathrm{cu})\end{array}$ & $\begin{array}{l}\text { inato } \\
\text { ivars) }\end{array}$ & & & & & & & \\
\hline
\end{tabular}

These results agreed with that obtained by Hesse (1976), who stated that Durado cv is considered self-unfruitful as well as Santa-rosa cv which appeared to be cross-unfruitful with Durado cv. Kloppers and Hadlow (1976), they found that Eldorado cv was good pollinator for santa-rosa cv. Carvalho and Raseira (1992) noted that santa-rosa cv seemed to be self unfruitful.

\section{Pollen viability}

Data presented in Table 3 show pollen viability of Sedik, Zebda, Hindy, Ewais and Langra mango cvs. Results indicated that Ewais cultivar had the highest rate of pollen viability in comparison with other cultivars $(72.4 \%)$ followed by Sedik $(36.3 \%)$ then Zebda $(23.0 \%)$ while this percentage in Hindy cv was $(12.8 \%)$. Such results are in harmony with the findings of (Dahshan, 1971) who reported that viability of pollen grains differs according to the time of inflorescence emergence and its position on panicle. He found that pollen grain viability of Zebda cv was $70 \%$ while this percentage in Taimour cv was (35\%) in early inflorescence and increased to $65 \%$ in normal and $74 \%$ in late inflorescence, he added that the viability of pollen grain in both cvs were higher in terminal parts of inflorescences but decreased towards the basal parts. In addition Lee (1980) found that the germination rate in vivo of some plum cvs varied considerably from one year to other and the rate was higher in vivo than in vitro (ranging from $32 \%$ to $96 \%$ ). Also Bozhkova (1995) classified pollen germination of prunus cerasifera varites into four gropes; low (up to $42 \%$ ), moderate (43-62\%, high $(63-81 \%)$ and very high (over $81 \%)$.

Egypt. J. Hort. Vol. 42, No. 2 (2015) 
TABLE 3. Percentage of pollen viability of the studied mango cultivars.

\begin{tabular}{|c|c|c|c|c|c|}
\hline Sedik & Zebda & Hindy & Ewais & Langra & L.S.D \\
\hline 36.3 & 23.0 & 12.8 & 72.4 & 14.3 & 5.2 \\
\hline
\end{tabular}

\section{Anatomical study}

Compatibility and/or incompatibility between the studied mango cultivars:

Pollen tubes characteristics in Ewais style after. Pollination with different pollen donors (Fig. 1).

A) Ewais X Sedik: The germination of pollen was poor on Ewais stigma and the style tissue senesced after 7 dayes from pollination

B) Ewais X Langra: With Langra pollen grains: a lot of pollen could arrive to the stigma of Ewais, but could not germinate.

c) Ewais selfing: microscopic examination revealed that most of pollen grains could not arrive the stigma and there is a varying degrees of self incompatibility.

d) Ewais X Hindi: when Ewais mango flowers were pollinated with Hindi pollens most of the pollen grains germinated on the stigma surface and its growth visible in the upper part of the style but they could not rich the ovary. The microscopic examination in this combination revealed varying degrees of cross incompatibility characteristics.

e) Ewais X Zebda: poor pollen grain arrive to the stigma and there is a senesces in the tissue after 7 days from pollination. Lee (1980) found that pollen tube growth was positively correlated with the amount of pollen on the stigma. A positive correlation was found between rate of pollen germination in vitro and pollen tube growth in the style.

Generally, it could be said that Ewais cv is considered as self-incompatible, whereas, Sedik, Langra, Hindi and Zebda are considered as partially crossincompatible for Ewais cultivar. 


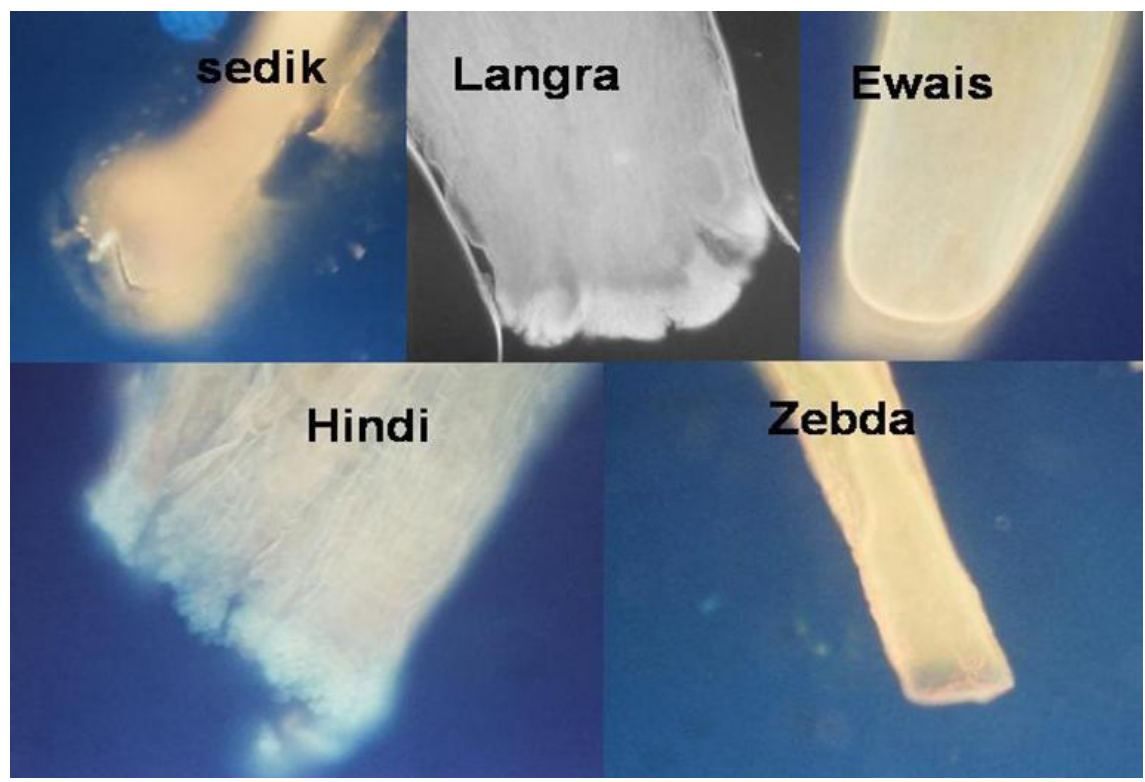

Fig. 1. Sedik, Langra, Ewais, Hindi and Zebda mango pollen grains germination on Ewais mango flowers stigmas.

Pollen tubes characteristics in Langra style after cross pollination with different donors (Fig. 2).

A) Langra (selifing): a little number of Langra pollen grain could arrive the stigma of Langra flowers. The pollen tube grows very slowly in the style. The microscopic examination in this combination revealed varying degrees of self incompatibility.

B) Langra X Sedik : there was a little number of germinated pollen on the stigma surface of Langra cv. But produced short pollen tubes with plugs which was unable to pentrate the stigma. Stott (1972), Stosser \& Anvari (1982), Abou ElNasr (1987) and Brain et al. (1989) reported that, incompatible tubes continuous depositions. Along the tubes and obvious terminal plugs.

C) Langra X Zebda: The germination of pollen was very poor and the pollen tubes grew very slowly and stopped its growth early. Pollen tubes of Zebda showed abnormalities which led to stopping their growth.

D) Langra X Hindi: illustrated presence of distorted pollen tubes, short tubes which were unable to penetrate the stigma as well as swelling tube tips. Partial cross incompatibility was observed when Langra flowers were pollinated with Hindy pollens.

E) Langra X Ewais: show that the surface of the stigma of Langra cv is empty from pollen germination, this means that Ewais $\mathrm{cv}$ is partial cross incompatibility for Langra. 
Generally, it could be said that Langra cv. could be considered as selfincompatible, whereas Sedik, Zebda, Hindy and Ewais are considers as partially cross incompatible for Langra cv.

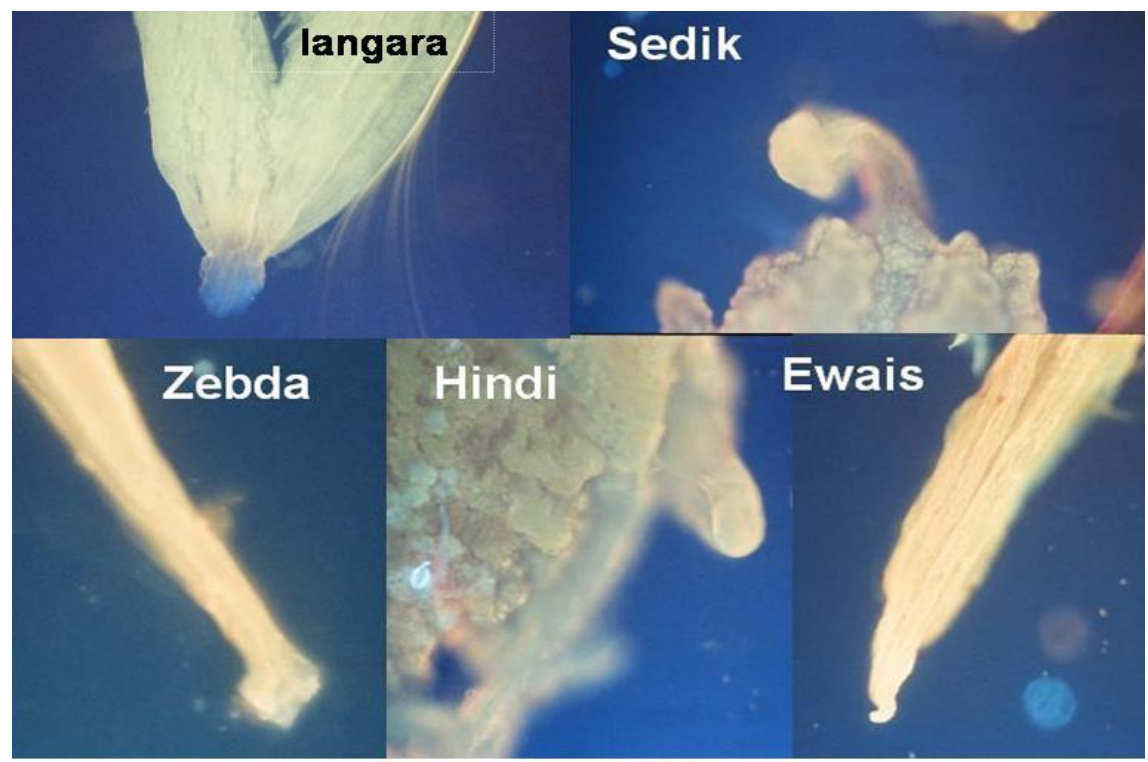

Fig. $\overline{2}$. Sedik, Langra, Ewais, Hindi and Zebda mango polin grains germination on Langra mango flowers stegmas.

Pollen tube characteristics in Sedik style after cross-pollination with different pollen donors (Fig. 3).

A) Sedik X Langra: Most of pollen grains germinated on the stigma surface and pollen tubes were visible in the upper part of the style and grew to about $1 / 3$ of the style length then stopped. However, some of pollen tubes showed abnormal growth.

B) Sedik X Hindi: Microscopic examination revealed that there is deposition of cullose along the tube. Terminal cullose plugs were present in most of pollen tubes, which indicated pollen tube incompatibility.

C) Sedik X Sedik (selfing): In this combination the stigma has a few pollen grains which could not germinate. The germinated pollen of Sedik cv was very poor on the stigma. Pollen tube showed abnormal development, they stopped its growth early in the style.

C) Sedik X Zebda: Microscopic examination in this combination revealed that pollen tubes of Zebda cv grew in the style of Sedik cv with different rates and failed to reach the end of the style.

D) Sedik X Ewais: In this combination most of pollen grains germinated on the stigma surface, its growth reached about $2 / 3$ length of the style then stopped. In addition, microscopic examination revealed varying degrees of crossincompatibility. 
Generally, it could be said that Sedik as a female parent seemed to be partially cross-incompatible with different pollen donors (Langra, Hindi, Zebda and Ewais). In addition Sedik cv seems to be self- compatible.

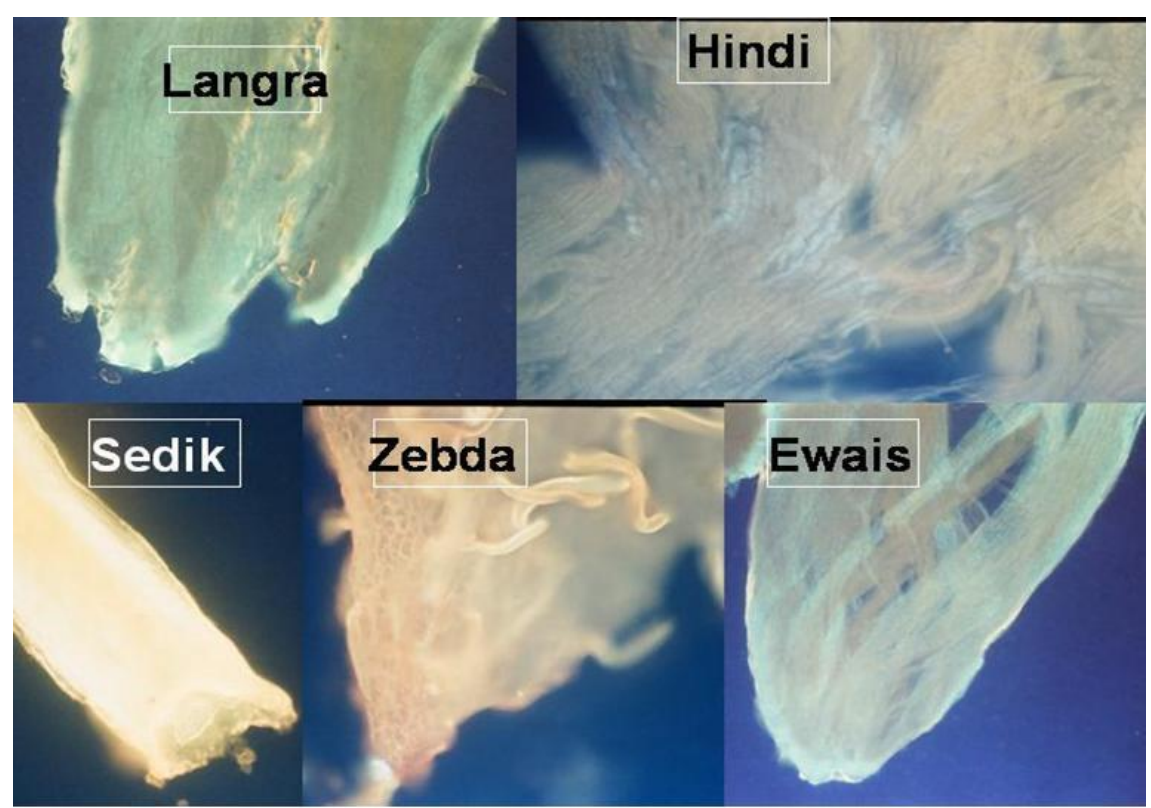

Fig. 3. Sedik, Langra, Ewais, Hindi and Zebda mango pollen grains germination on Sedik mango flowers stigmas.

\section{References}

Abou-EInasr, N.M. (1987) The development of ovules by diploid and triploid apples varieties. Ph.D. Thesis, Faculty of Agriculture, Hohenheim Univ., W. Germany.

Abou-Elnasr, N.M. and Wanas, W. (1992) Effect of floral application of some growth substances on pollen germination and ovule viability of two apple cultivars. Annals Agric. Sci., Ain Shams Univ., Cairo, 37 (1), 223-233.

Afify, A. (1933) Pollen tube growth in diploid and polyploidy fruits. J. pomology Hort. Sci., 11, 113-119

Ali, N. and Mazhar, H. (1960) The tree flower and fruit characteristics of the mango. Punjub Fr. J., 23 (82, 83), 80-86.

Anvari, S.F. and Stosser, R. (1978) A new fluerescence microscopic method for the determination of the viability of ovules prunus. Z. Pflenzenzucht, 81, 333-336.

Bozhkova, V. (1995) In vitro pollen germination of myrobalan plum varieties and forms Rasteniev dui Noukii, 32 (3), 99-100 (Hort. Abst. 66 (6), 4860).

Egypt. J. Hort. Vol. 42, No. 2 (2015) 
Brain, A., Bircenkoff, A. and Stang, E.J. (1989) Pollination and pollen tube growth in relation to cronberry fruit development. Amer. Sci. Hort. Sci., 114, 733-737.

Carvalho, T.V.P. and Raseira, M.C.B. (1992) Compatibility among cultivars adapted to southern Barazel. Fruit Var. J., 46, 28-35.

Chandbr, W.H. (1958) "Evergreen Orchards", $2^{\text {nd }}$ ed., Henery Kimpton Landon, 535p.

Currier, H.G. (1957) Callus substances in plant cells. Amer. J. Botany, 44, 478-488.

Dahshan, D.I.M. (1971) Studies on concerning growth and fruiting in some mango varieties. MSc. Thesis, Faculty of Agriculture, Ain Shams University, Cairo, Egypt.

Han, D.W. and Lee, J.J. (1972) Effect of Ethrel, RH531 and gibberellin on the sterile pollen induction in lettuce. Thesis Seoul Municipal Coll. Agric. Plant. Breed. Abst: 4774 .

Hesse, C.O. (1976) Durado a new fresh market plum. California. Agric. 30, 12-13.

Kho, Y.O. and Baer, J. (1970) Die fluoreszenz mikroskopie in de botanischen Forschung. Zeiss Inf., 18, 54-57.

Kloppers, F. and Hadlow, J.V. (1976) Cross pollination for songold plums. Decidus fruit grower, 26, 328-330. (Hort. Abst 47 (4), 3372).

Lee, C.L. (1980) Pollenkeiming, pollenschlauchwachstun and befruchtungsverhaltnisse bei Prunus dlomestica. Dissertation, Hannover, p.120.

Modlibowska, I. (1945) Pollen tube growth and embryo sac development in apples and peurs. J. Pomol., 21, 57-89.

Oberle, G.D. and Watson, R. (1953) A method for evaluating pollen production of fruit varieties. Proc. Amer. Soc. Hort. Sci., 59, 263-265.

Schmadlak, J. (1965) Untersuchungen des pollen schlau- chwuchstums in Apfelgriffen. 1. pollenkelmung auf der griffelnerbe Affinitatsko effizient . und Einringtiefder polleuschliuche in dem Griffed. Archiv Fur Gurtenban, 13, 497-513.

Singh, K.K. (1960) Mango growing in punjab. Punjab Fr. J., 23 (82,83), 215-220.

Snedecor, G.E. and Cochran, W.G. (1980) "Statistical Methods", $7^{\text {th }}$ ed., Iowa State Univ. Press, Ames, Iowa, U.S.A.

Spencer, J.I. and Kennard, W.C. (1955) Limited stigmatie receptivity may contribute to low fruit set in the mango. Proc. Amr. Soc, Hort. Sci., 67, 287-296.

Stosser, R. and Anvari, S.F. (1982) On the senescence of ovules in cherries. Scientia Horticulturae, 16, 29-38.

Stosser, R. and Anvari, S.F. (1983) Pollen tube growth and fruit set as influenced by senescence of stigma, style and ovule. Acta Hort., 139, 13-22.

Egypt. J. Hort. Vol. 42, No. 2 (2015) 
Stott, K.G. (1972) Pollen germination and pollen tube characteristics in orange of apple cultivars. J. Hort. Sci., 47, 191-198.

Williams, R.R. (1970) Factors affecting pollination in fruit trees. In : Physiology of Tree Crops, L.C. Luck will and C. V. cutting. (Ed.), pp.193-208.

Williams, R.R., Brain, P., Church, R.M.and Flook, V.A. (1984) Flowers receptivity pollen transfer and fruit set variations during a single flowering period of (Coy'S) orange pippin apple. J. Hort. Sci., 59, 337-347.

$$
\begin{aligned}
& \text { التوافق الأاتي والخلطى لبعض أصناف المانجو } \\
& \text { نادى حسن نادى و سناء سامى عبيا }
\end{aligned}
$$

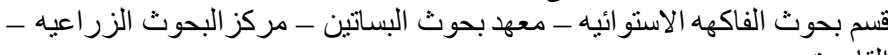

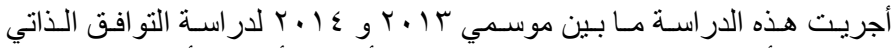

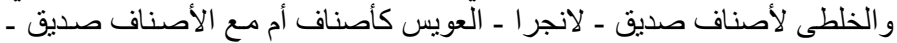

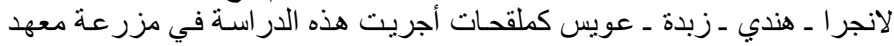

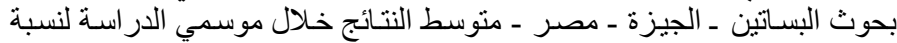

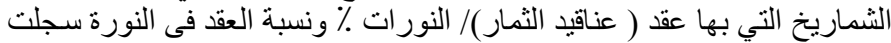

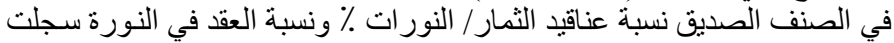

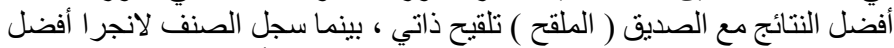

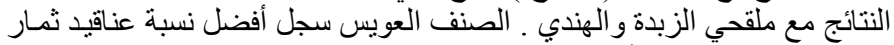

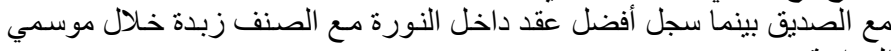
الدراسة.

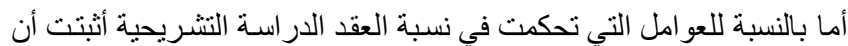

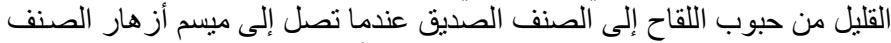

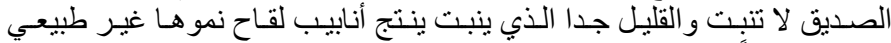

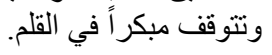

أما علي مباسم أزهار الصنف لانجر ا وصول حبوب اللقاح الزبدة إليه كان قليل

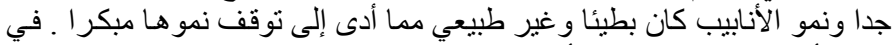

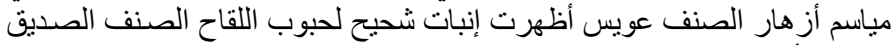

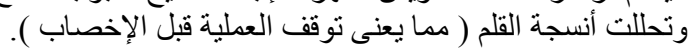

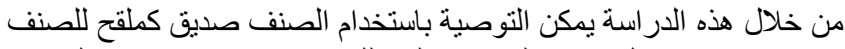

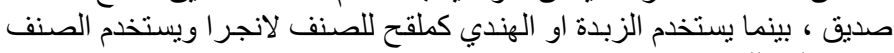
زبدة كملقح للعويس.

Egypt. J. Hort. Vol. 42, No. 2 (2015) 